\title{
Aleut Language
}

National Cancer Institute

\section{Source}

National Cancer Institute. Aleut Language. NCI Thesaurus. Code C153831.

The sole language in the Aleut branch of the Eskimo-Aleut language family. It is spoken by the Aleut people living in the Aleutian Islands, Pribilof Islands, Commander Islands, and the Alaskan Peninsula. 